\title{
Being a Muslim Woman in Contemporary Indonesia (Me, Islam and Diversity)
}

\author{
Ayu Arman \\ Muhammadiyah Young Intellectual Network (JIMM) \\ ayu.arman6@gmail.com
}

\author{
Abstrack- The peak of lovey is rebellion \\ A process of liberating oneself from falsity \\ Toward an essential self \\ In finding one's natural self
}

\section{ROOT: KEJAWEN, NU AND MUHAMMADIYAH}

I was born and raised a Muslim. It means that I embraced Islam, the monotheistic religion descended to the prophet Muhammad SAW in the Arabic peninsula, as a sacred legacy that my parents inherited to their children.

My parents, especially my father, is a "straight" Muslim. My father is a pious man who refuses all kinds of religious practices which are not based on syariah laws, especially those of magical heresies like worshipping the grave or trees. He's not the kind of person who believes in supernatural powerslike what most people in my hometown Latek, subdistrict Sekaran, district Lamongan, East Java province believe in.

I do not know exactly when the teachings of Islam came into and when Islam became the main religion in my village. According to the elders, the villagers used to be Hindus before they converted to Islam. So, at that time it was common to see villagers practicing the Hindu tradition of sadran, doing ritual offerings, or visiting places believed to have supernatural power.

Nahdlatul Ulama (NU) is the first Islamic organization entering this village after Masyumi party collapsed in the 1960s. NU is the biggest traditional islamic organization in Indonesia. Founded by Kiai Hasyim Asyari in 1926, its purpose among others is to hold back the rapid growth of Islamic purification movements done by several prominent figures of Wahabi in Indonesia. Those movements are

\footnotetext{
${ }^{1}$ Takhayul=An adjective describing an act or attitude that believes in something that can't be scientifically proven.

${ }^{2}$ Bid' $a h=$ New ritual practices which do not exist in Islam, was never done at the time of the prophet, and do not based on AlQur'an and Hadits.
}

considered to have tendency to destroy Indonesian cultures. NU chooses traditional approach to villagers, which are nonoffensive to local cultures. NU, for instance, approves the rituals done when someone passed away like chanting prayers, doing tahlilan, reciting the Quran (yasinan) on the 7th, 40th, 100th, and 1000th days, visiting the graveyard, and reciting short prayers to the prophet(diba'an).

However, my father had a different perspective. He refused to accept islamic practices mixed with the local tradition: the tradition that his parents, his extended family, and almost the whole village strongly believed in. His new religious perspective brought him to Muhammadiyah, an organization known as NU's "enemy".

Yes, besides NU, Muhammadiyah is the largest Islamic organization in Indonesia. Founded by KH. Ahmad Dahlan in 1912 in Kauman Yogyakarta, the organization is a pioneer in reforming movements to purify the Islamic belief from all kinds of deviating ritual practices and bid'ah. From the social aspect, Muhammadiyah cleans religious practices from khurafat (mixing the Islamic teachings with superstitious things (takhayul)). From the intellectual aspect, the organization which rose and developed in urban society, tries to eliminate the practice of idolizing certain prominent religious leaders and gives the freedom to its members or followers to do ijtihad (independent reasoning). This reformation is also known as TBC. The fact that TBC is the abbreviation of tuberculosis, a dangerous and contagious disease, Muhammadiyah also used the term to describe Takhayul $^{l}$, Bid 'ah $^{2}$, and Khurafat ${ }^{3}$. Like tuberculosis, these three deviating beliefs of some Muslim people are believed to be just as dangerous [1].

My father's choice on Muhammadiyah at that time was probably because he was once a student at SMP Muhammadiyah Lamongan, although never graduated. It could also because he read kitab kuning Nasihin, the book

\footnotetext{
${ }^{3}$ Khurafat $=$ The act of bid'ah.
} 
used by Lembaga Dewan Dakwah Islamiyah (LDDI). Or the influence might come from newspapers, magazines, and books he read. Reading is indeed my father's hobby. He especially loves reading historical religious books.

To my father, Muhammadiyah is an important liberating movement that helps someone become a free individual both physically and mentally. He believed this organization protects its members from physical and spiritual's slavery because humans are only allowed to obey the one and only Allah.

Initially, there are only a few Muhammadiyah's followers in my father's hometown. The branch of Muhammadiyah in my village was built by $\mathrm{H}$. Makrib, one of the residents of Latek who disagreed with some of the religious practices in our only masjid. His refusal over these practices encouraged him to separate himself from the masjid and then built a langgar ${ }^{4}$ with several other residents who shared the same perspective with him.

It was in this langgar that my father spent most of his youth. He was then appointed as the head of Muhammadiyah's branch during the 70s to the 80s after the leadership of $\mathrm{H}$. Makrib. With his two other friends $-\mathrm{H}$. Podho and H. Syuuni (widower)-my father then built Madrasah Ibtidaiyah (elementary school) of Muhammadiyah, and he became the first headmaster in the school which had only 10 students.

When the number of students was increasing, my father started to look for teachers from neighboring villages. Not only did my father teach, he was also responsible for the funding and other Muhammadiyah's activities. In his spare time, my father opened a business of rice milling, and rice trading. He also did some farming. The profit of these businesses was often used to pay for the teachers' salary.

It was in this school my father met my mother. She was a Muslim girl who lived not far from the school and the praying house. My mom came from a Muslim "abangan" family, the kind of Muslims who claimed themselves to be Muslims yet their daily life was still following local beliefs (kejawen). Almost all of my grandmother's relatives (from my mother's side) believed in "Sapto Darmo"," one of kejawen's big sects in Indonesia. While my grandfather was an NU follower who loved wayang (shadow play with leather puppets).

\footnotetext{
${ }^{4}$ Langgar=praying house which size is smaller than a mosque.

${ }^{5}$ Sapto Darmo (One of Kejawen's big sects in Indonesia.) founded by Hardjosaputro in Pare-Kediri- East Jawa. The name Sapto Darmo was taken from Javanese language. Sapto means seven and darmo is holy obligation and religious service (1)Wahyu Sujud: the ritual of sujud (head on the ground)/ worshipping God (Allah Hyang The Almighty); (2) Wahyu Racut: human's spiritual way to know alam langgeng or practice sowan/facingHyang The Almighty;(3)Wahyu Simbol Pribadi Manusia: the origin, the nature, the character of human themselves, and ways to control their desire in order to achieve magnanimity;(4) Wewarah Tujuh:
}

I grew up with these three different cultures: Muhammadiyah, NU, and Kejawen. Since I was a kid, I used to see my immediate families practiced their religion in different ways. From my grandfather (from my mother's side), I learnt the kejawen traditions like bathing the keris (wavy double-bladed dagger) and the spear every Syuro 1 (the Javanese calendar), listening to gending Jawa (the traditional musical composition using gamelan) and wayang stories. I also learnt the way they prayed: sit quietly with legs crossed and eyes closed facing towards the east. I also could see how my great-grandfather unsheathed his spear upward to the sky while chanting prayers to stop the heavy rain and the thunderbolts.

I learnt and sometimes did prayers in the mosque using qunut, did shalawatan, tahlilan, and took part in the rituals when someone passed away. I learnt all those things from my grandparents (from my father's side). While from my father, I learnt that all aspects of our life had to be based on Alquran and hadits. If someone did a religious practice which had neither guidance nor example from both books, then he or she had conducted the act of takhayul, bid'ah, and khurafat. Those who did these acts are sinned and would be put in hellfire.

It was still clear in my mind the day I received "berkat" from a neighbor whose relative has just passed away. "Berkat" is a package of food consists of rice, a piece of chicken, egg, noodle, and my favorite apem (rice flour cake). When my father found out about it, he immediately threw the package away and fed the chicken in our front yard with it.

I remembered asking him, "Why did you throw the food away, Dad? I love the apem cake."

"It's haram. You can't eat them," answered my father briefly. If he had said so, no one could argue him.

I really hated my father when he threw away food whenever I received "berkat". It was in the fifth grade of elementary school when I had the courage to ask my father more about it.

\section{"Why can't I eat the berkat?" I asked.}

"Our prophet never taught us to do such thing. Besides, do you have a heart to eat food from a grieving family whose

humans' obligations in their relation to Allah Hyang the Almighty, government and the state, the country, and the nation, in relation among humans as social creatures, as individual creature, as part of their community and environment who believed that the world is not eternal; and(5) Wahyu Sesanti: the ethics/characteristics of Sapta Darma which emphasize on the notion that one has to be useful to others/ make others happy (tansah agawe pepadang lan maraning lian). 
relative has just passed away? We are supposed to help them, give our donation to them, instead of receiving something from them," explained my father. "Besides, such ritual has no guidance from the Qur'an and hadits."

I didn't argue him. My father is authoritarian. He doesn't like people to argue or disobey him. His words are our command, and that includes all family members. Since I was a kid, I had to pray on time, recite the Qur'an, and wear hijab. My father didn't hesitate to hit me if I missed a prayer. If I didn't wake up before the call (adzan) for subuh prayer, my father would soak my face and head with water. I also couldn't cut my hair short, because only boys are allowed to have short hair, and it's a sin if a girl looks like a boy.

I obeyed all of these dos and don'ts from my father except for one, he couldn't make me stop taking my dancing class. I have loved dancing since I was very little. My body moves every time I hear music, especially gending jawa, the kind of music I learnt from my grandfather. I often created my own dance moves and taught them to younger kids. I usually performed at school's farewell party and tirakatan night (an event held to commemorate the Independence Day on August 17).

My father would get angry if he found out that I practiced dancing. He often told me that it's a sin for a girl to expose certain part of their body or perform in public. At that time I really didn't understand what that means. I didn't even understand what sin is, just as I didn't understand why I spontaneously danced whenever I heard gamelan.

All I know is that if I disobeyed my father, he would have been very angry. But I couldn't refrain myself from learning dancing even though my father clearly forbade me to do it. Off course I did it behind his back. I usually practice my dancing moves at my friend's house or at my grandfather's house. Until one day, my father heard that I was learning Jaipongan dance to commemorate the Independence Day. He looked for me and when he saw me dancing, he took the tape and the cassette, and smashed them to the floor without saying a word. My friends and I were terrified. The performance was then canceled.

At the age of 13, I left my village to continue my study at Pesantren Karangasem, Paciran, Lamongan, an Islamic boarding school founded by Muhammadiyah. Pesantren is an Islamic educational institution which upholds traditional Javanese values. As an institution focusing on religious education, every student should follow rules and regulation strictly. A fixed schedule was set to arrange students'routine activities from the time they wake up to the time they go to bed.

My friends and I barely knew what was going on outside our pesantren. Our only contact to the outside world was a TV that could only be watched on Fridays and Jawa Pos newspaper displayed in our school hall. We were also not allowed to communicate with male students. The pesantren caretakers would reprimand and even punish us if they found out we made contact with the male students; even peeking at them from our windows was forbidden.

The punishment for such action was embarrassing. We had to clean the male students' dorm and bathroom for days. The punishment was even worse if one female student was caught having a relationship with the male student. They could be expelled from the school, because such relationship was considered a disgrace to the school.

Even though I had very limited access to the outside world, the school had introduced me to different cultures in Indonesia. Through my friends who came from different parts of Indonesia, I learnt about Bali, Banyuwangi, Situbondo, Surabaya, Malang, Jombang, Gresik, Madura, Bawean, Jakarta, even Sulawesi, Kalimantan, and Sumatera. I learnt about specific character and unique accent of people as well as their local food from my fellow students. After school holiday, we usually shared our experience and stories from our hometown. I then realized that the first time I learnt about pluralism was actually not from the school subjects like Geography and Pendidikan Moral Pancasila (PMP), but from my interactions with my friends in pesantren.

Pesantren also taught me to be an independent and disciplined person. I was trained to live apart from my family and do everything all by myself. The school also taught me about the true meaning of sharing and togetherness.

The first three years of my pesantren's life didn't improve my Islamic knowledge much. My knowledge didn't go farther than the kind of Islam which strongly opposed the products of cultures from the local people's life. It was all because at this level of education, I only studied Al Jalalain, the book of Alquran's interpretation which was considered as a classic interpretation of Mazhab Sunni; Bulughul Marom; and learnt the rules of Arabic language, like Nahwu and Shorof.

My understanding of Islam started to change when I went to Madrasah Aliyah Program Khusus (MAPK) or a special program for Islamic high school students; an exemplary project for Madrasah education initiated by the minister of religious affairs since the 1980s. This program selected students from Islamic schools in Karangasem pesantren who excelled in academic field. In this program, the students spent $70 \%$ of their time to study Islamic knowledge using Arabic language, and 30\% to study popular knowledge. Each student was obligated to memorize the Qur'an. To achieve maximum end result, the boarding house of MAPK students was separated from the regular students.

This madrasah had a very strict discipline. There was no holiday for students except on Friday. Activities started at dawn and ended at 10 P.M. The morning started with the 
activity of reciting one page of the Qur'an that the students have memorized to a teacher after subuh prayer. I was one of the selected students. We studied using Arabic as classroom language proceeded by afternoon tutorial on the yellow book (kitab kuning).The same tutorial would continue after the isya prayer until 10. P.M.

It is in this MAPK I first encountered various kinds of the yellow books, such as (1)The book of Mushtholah Al-Hadits; (2)Fiqh al-Sunnah-al-Sayyid Sabiq; (3)Mana'ul Qatan Mabakhis fii Ulumul Quran;(4) Syari' Ibnu Aqil;(5)Fajrul Islam; (6) Subulus Salam;(7) Fatkhul Majiid; (8) Kifayatul Akhyar; (9)Mulakhosh Lughoh Arabiyah; and (10) Alfiyah and Shorof.

From studying these books, I began to a have a broader knowledge on Islam, I began to understand that there were diversity of thoughts and mazhabs in the civilization of Islam. I learnt the differences (khilafiyyah) of mazhabs when I studied Fiqh (the law of Islam) written by Sayyid Sabiq. These differences were the result of different understandings and different approaches of each imam. There are five prominent fiqh mazhabs that still exist up to this day, they are Hanafi, Malik, Syafi'i, Hambali, and Syiah Imammiyah. The difference of these mazhabs due to the different sociology and political orientation of these imams as also different methodology they used to study the law from its main sources: Al-Qur'an and hadits [2].

I also learnt to analyze the quality of a hadits that became one of the postulates in deciding one Islamic law. When I studied the book of Mushtholah Al-Hadits written by al Qodhi Abu Muhammad ar-Romahurmuzi, I learnt more about hadits. It is from this book, which was written by the request of the khalifah (leader of the nation) Umar bin Abdul Aziz, I understood various kinds of hadits, criteria of hadits, the requirements for someone considered eligible to narrate a hadits, and other things that could be used as evidence of the validity of the content of a hadits.

The more I learnt about this yellow book, the better my understanding on Islam was. I finally understand that Islam has its ups and downs. In the era of the prophet and the Khulafa'al-Rasyidin (632-661) the expression of Islam is relatively similar. In the era of the prophet Muhammad SAW, all problems arose among the Muslims could be solved within his authority. The ummah (the followers of the prophet) had this Sami 'nawaattho'na (we listen and we obey) attitude. It's the attitude of listening and obeying the prophet without questioning or doubting his words at all.

When I first read religious texts in these various yellow books, I had so many questions in mind. As a Muslim woman, all of my intention, thoughts, and attitude should always follow the rules of Al-Qur'an, hadits, moral values, and fiqh (Islamic laws). These sources have to be my guideline and reference. My activities from the time I wake up to the time I go to bed, from the day I was born to the day I die all have to follow these guidelines and references.

The problem was the more I referred to these texts, the more I felt that these texts were being unfair to my gender, to women. Say for example the text about the creation of woman from the prophet Adam's crooked ribs; the idea that women were created "half"than men made them could never be a leader; also about the text that said "If a man calls his wife to bed and she refuses, and then he sleeps angry, the angels shall curse her until he awakens"; about women's testimony, about the inherintance a woman received, about polygamy, also about the text that says women's voice is aurat (forbidden) because they tend to trigger slander [3].

Why do men have more priviliges than women? I asked this question to my teachers and the answer was always the same: "Because men were destined to be leaders."

Of course that was not a satisfactory answer. I was once read a book that said, "A man of faith will be rewarded a beautiful female angel in the heaven." I was so upset that I threw the book to the gutter.

I read carefully whether there was a statement saying that a woman of faith will be rewarded with a beautiful male angel. Why were only men? There was no answer; I became more and more curious and restless.

I found out the answer to my questions later when I was in the third semester of college in the State Islamic University (UIN) of Syarif Hidayatullah, Ciputat, Jakarta. I then realized that the discrepancies happened because of a bunch of cultural legitimations and patriarchal religious understanding.

\section{UIN SYARIF HIDAYATULLAH-JAKARTA: The SEEDS of REBELLION}

I want to see a world without discrimination between men and women. And to realize that gender justice had to be upheld proportionally including in the Islamic world. Gender in figh took the men's side because the books were written by men. This injustice had made me wonder and worry at the same time.

I know that Al-Qur'an and hadits are two main sources of the teachings of Islam. We were always told that there was no doubt at all about these two sources. Al-Qur'an and hadits talk about women as an individual, a wife, and a part of the society. But these two references have two different delineations about women.

In terms of emancipation of human beings, Al-Qur'an apprehends women as individual who have equal rights as men. If a woman does something good, they will be rewarded 
the same merit as man. But in terms of domestic life and marriage, Al-Qur'an interestingly withdraws the equality between man and woman.

Al hadits is no different. There are hadits which hold equality between men and women, but there are also hadits which describe inequality or known as misogyny - hatred over women. Then how do we understand the tendency of Alquran and hadits in describing equality between men and women? Or was it true that socially, Islam placed women as second class creature?

To understand this, the first thing we have to remember is that Islam is not Arab even though it was descended in the land of Arab. We have to be able to distinguish between the doctrine teachings of Islam and the culturally-based teachings of Islam. We have to understand what the reasons of the revelation of a hadits are.

The second thing, Islam came as a liberator. It was descended in the Arabic peninsula as revolutionary moment. We have to remember that there were contradictions in the people of Arab before the prophet introduced Islam. On the one hand, the pre-Islam Arab society had strong literary and trade tradition. On the other hand, there was a system of oppression over a certain community groups, in this case women and slavery over the poor.

Some revolutionary teachings of the prophet Muhammad SAW are the emancipative demands; the call for egalitarian social structures in ritual life (like sholat and zakat), in social life (gradual abolition of slavery), in economy - politic (opposition toward accumulating wealth and economic monopoly by a number of big traders) and the relationship among people of different religions.

But the universal revolutionary call from the Qur'an did not neglect the social context of ignorant Arabic society. The abolition of slavery for example was done gradually so that the liberation of the oppressed become the realization of the highest humanitarian struggle in Islam. Because according to Qur'an, protecting the oppressed is a definite must. (QS 4: 75)

Hence, the interpretation of inequality had to be based on historical approach, since the impression of inequalities in Alquran and hadits often emerged in certain historical contexts which were then interpreted by experts (who were mostly male) by using dzahiryyah approach.This approach tried to understand Qur'an based on what was written and completely ignored the historical context.

In the study of tafsir, textual interpretation is the oldest approach in religious studies which is often used by many groups, including the Muslims at modern time. And those with such perspective usually had a very rigid attitude toward the religion and rarely compromised with the social, politic, and cultural changes around them.

If Alquran is interpreted contextually, both in the context when Alquran was sent down to the prophet and in the context of present day, the result will be different. Interpreting Al-Qur'an by using its context opens the room for emancipation for both men and women.

But this kind of interpretation is still unfamiliar and difficult to be accepted in communal life. Often times, those who understand the significant of gender equality experienced deadlock when they deal with the real life situation. When there is a woman who is stubborn enough to fight for their life and destiny, they are often considered as "rebellious women" or "liberal women."

It's still clear in my mind when I decided to no longer wear my veil. Veil is a Muslim women's clothing, the obligation to wear it is regulated in Q.S An-Nuur (24):31 and Q.S AlAhzab (33):59. These two verses of Qur'an give legitimation to the sanctity of a woman in their family and public space. Unfortunately, the social context of these verses of Qur'an are rarely revealed. Therefore veil or jilbab is presumed as the substance of religious teachings, a symbol of piety, and obidience of someone to the religious authority.

For me, veil is not an obligation for muslim women, it was only an expression of Arabic culture. In my opinion, veil is only a game of meaning and interpretation.

The power relation between normative preacher and liberal preacher; between norms (taboo, aurat, sanctity, and privacy) and women liberation (space, equality, etc). Therefore, I consciously decided not to wear the veil anymore, a clothing that I've been wearing since I was a kid.

What were the reactions of people around me when they saw me no longer wearing my veil? Friends, villagers, friends in pesantren, friends in Muhammadiyah organization were being cynical at my decision. They blasted various accusations like: I have turned into a liberal woman, that I have a weak faith in the religion, that $i$ have been influenced by hedonistic metropolitan lifestyle. The accusation got even worse when I became a single parent.

As predicted, my family, especially my father and mother, felt ashamed of my very "brave" decision. They felt humiliated by their own daughter. My father kept on insisting me to wear my veil. But I was confident with my opinion that jilbab or veil is not an obligation for Muslim women. It was only an Arab culture and I told him that I feel more confident not wearing it. Our arguments ended up only making my father more upset.

My father was so upset that once he trew the ironing at me. He also didn't speak to me for months. My mom was depressed because of me whom she thought has went astray 
from the Islamic syariah law. Deciding not to wear veil was one of my rebellion to my parents to religious restrictions, before my many other "rebellions."

The education I received in Pesantren and the State Islamic University (UIN) that my father had chosen for me, on the one hand, had made me become an independent and openminded person over the subject of Islamic teachings. But on the other hand, it had also made me and my father stood in opposite direction.

I have made my choices and I know the consequences that I have to bear. I did my best to deal with them. And today, after an exhausting struggle, I can prove that I'm comfortable with my choice of not wearing any religious attributes in my body.

I know I have hurt my parents' feeling. But from the bottom of my heart, I still love them with my own way. Because for me, the peak of love is rebellion, a process of liberating oneself from falsity, toward an essential self, in finding one's natural self.

Therefore, rebellion is often needed when we are trapped in certain situation and condition. And every rebellion has its price. You have to be ready to be slandered or even bullied. But I do believe that when you have found your inner self, and have become yourself, dan have control over yourself, then you have the immeasurable happiness in this world.

\section{ACKNOWLEDGING INDONESIA'S DIVERSITY}

The search for the meaning of diversity and contemplation on life in the world of literary had given me the opportunity to visit several places in Indonesia. Since 2009, for more than half a decade, I have gone back and forth between Jakarta and Raja Ampat (Papua), a beautiful place with the world-known marine life. Other than for the assignment of writing the biography of the founding father of the district, I also observed the local people's religious life. The local people who have different religious beliefs could live harmoniously and work hand in hand in religious celebrations (Islam, Catholic, Christian) and in traditional celebrations. In my opinion, the people of Papua are open and tolerant with other religions. I often witnessed how events were started and ended with prayers from two religions: Islam and Christian/Catholic.

In 2011, I was blessed with an opportunity to learn about the local culture of West Halmahera, Maluku. I visited the place to write biography of its first district head. The place suffered from religious disputes in 1999. I could still see ruins of houses and I could still feel suspicious looks of the people toward strangers. When I asked some local people the reasons for this social catastrophe, nobody knew for sure. It happened just like that, so they said. Majority of the people of North Maluku considered this riot as a mere political game.
West Halmahera was quite fast in settling the conflict between religious groups. The decision to hold the festival of culture (Teluk Jailolo Festival), in my opinion, was an effective way out in recovering the disputes. The people worked together and again built their trust and togetherness. That way, the local people of West Halmahera could again built the ethnic unity despites the religious boundaries.

From North Maluku, I traveled to Central Kalimantan in 2013 to write bigraphy of the first leader of Murung Raya. I found out that this Tanah Dayak was rich in gold, coal, and oil. You could see also thousands of trees and rivers. In this place, I interacted with local people and learnt that the Dayak people still preserve their ancestor's religion "Kaharingan". This religion had its own rules and regulation for the believers to follow. The believers had to perform various ceremonies like Tiwah - death ceremony, and Balian - ceremony for treatment of the sick, and many others.

Even though majority of the Dayak people in Central Kalimantan had converted to Islam or Christian (50:50\%), both Muslim Dayak and Christian Dayak still perform Tiwah ceremony (burial ceremony Kaharingan). In this ceremony, the Muslim Dayak slaughtered the animal for religious offering (kurban) so that other Muslims could take part in. Furthermore, it's common to see one big family members have different religions. The awareness of religions could be seen in "Huma Betang", traditional house of central Kalimantan, which was built in a very huge size of $30-150 \mathrm{~m}$ in length, $10-30 \mathrm{~m}$ in width and 3-4m tall pillars. Dozens of people with different background and religions live in this house. They live harmoniously. The spirit of togetherness in diversity has been part of Dayak's society up to this day [4].

In 2014, from Kalimantan, I continued my adventure to Sulawesi, especially to Wakatobi in Southeast Sulawesi, West Mamuju in West Sulawesi, and Palu in Central Sulawesi. I was amazed by the tourism development in Wakatobi, Southeast Sulawesi, while in West Mamuju I was surprised by what I saw in a remote village. It was like I was transported to the set of the movie "Osama": Afganistan movie directed by Siddiq Barmak. I could barely see the female's face because most of the women and young girls aged 9-10 were all covered up from head to toe. You could only see their eyes.

From my journey: Papua, Maluku, Kalimantan, and Sulawesi, I came to conclusion that Islam in Indonesia is Islam with social integration system and harmonious strategies which is based on the authentic culture of the nation. But I can't argue that there are movements from several radical islamic groups, such as Ikhwanul Muslimin, Salafy, Hizbut Tahrir, and FPI which make both muslim and non-muslim restless because they spread the culture of violence. They are mostly minority groups which were originated from the Middle East culture. Therefore, for me, Islam in Indonesia is still struggling, competing between literary and contextual discourses; between exclusive and inclusive; between restrictions and liberation. And being a muslim woman in contemporary Indonesia must have an 
awareness and a worldview that Indonesia is not belonging to a group, not a religion, not a tribe, not belonging to a group of customs, but belonging to all of us Indonesia is a common home, as a result of the nation's consensus, which consists of various religions, tribes, regions, and skin colors. Indonesia is home place where we are to serve and show the best works.

Diversity in Unity is a necessity in Indonesia REFERENCES

[1] Hasyim, Syafiq (ed). Islam and Multikulturalisme, Jakarta, ICRP, 2008. Jakarta: ICRP, 2008.

[2] Syafii Maarif, Ahmad, dkk . Fikih Kebinekaan, Pandangan Islam Indonesia tentang Umat Kewargaan dan Kepempinan Non-Muslim, Mizan and Maarif Institute, 2015. Mizan and Maarif Institute, 2015.

[3] El Guindi, Fedwa. Veil : Modesty, Privacy and Resistance. Berg, Oxford, 1999. Berg: Oxford, 1999.

[4] Sahal, Akhmad (Ed). Islam Nusantara. Dari Ushul Fiqh hingga Paham Kebangsaan, Mizan, 2015. Mizan. 